\title{
Trust Law as Fiduciary Governance Plus Asset Partitioning
}

\section{Citation}

Robert H. Sitkoff, Trust Law as Fiduciary Governance Plus Asset Partitioning in The Worlds of the Trust (L. Smith ed., 2013).

\section{Permanent link}

http://nrs.harvard.edu/urn-3:HUL.InstRepos:15274284

\section{Terms of Use}

This article was downloaded from Harvard University's DASH repository, and is made available under the terms and conditions applicable to Other Posted Material, as set forth at http:// nrs.harvard.edu/urn-3:HUL.InstRepos:dash.current.terms-of-use\#LAA

\section{Share Your Story}

The Harvard community has made this article openly available.

Please share how this access benefits you. Submit a story.

\section{Accessibility}




\title{
THE WORLDS OF THE TRUST
}

\author{
Edited by \\ LIONEL SMITH
}

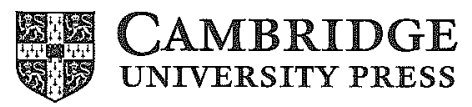




\section{CAMBRIDGE UNIVERSITY PRESS}

University Printing House, Cambridge CB2 8BS, United Kingdom

Published in the United States of America by Cambridge University Press, New York

Cambridge University Press is part of the University of Cambridge.

It furthers the University's mission by disseminating knowledge in the pursuit of education, learning and research at the highest international levels of excellence.

$$
\text { www.cambridge.org }
$$

Information on this title: www.cambridge.org/9781107032439

(c) Cambridge University Press 2013

This publication is in copyright. Subject to statutory exception and to the provisions of relevant collective licensing agreements, no reproduction of any part may take place without the written permission of Cambridge University Press.

First published 2013

Printed in the United Kingdom by Clays, St Ives plc

A catalogue record for this publication is available from the British Library

$$
\begin{gathered}
\text { Library of Congress Cataloging-in-Publication Data } \\
\text { Smith, Lionel, 1965- } \\
\text { The worlds of the trust / Edited by Lionel Smith. } \\
\text { pages cm } \\
\text { ISBN } 978-1-107-03243-9 \text { (Hardback) } \\
\text { 1. Trusts and trustees. I. Title. } \\
\text { K795.S65 } 2013 \\
346.05^{\prime} 9-\mathrm{dc} 232012049255
\end{gathered}
$$

ISBN 978-1-107-03243-9 Hardback

Additional resources for this publication at www.cambridge.org/9781107032439

Cambridge University Press has no responsibility for the persistence or accuracy of URLs for external or third-party internet websites referred to in this publication, and does not guarantee that any content on such websites is, or will remain, accurate or appropriate. 


\title{
Trust law as fiduciary governance plus asset partitioning
}

\author{
ROB ERT H. S I T KOF F
}

\section{Introduction}

Organizational law - a category that includes the law of corporations, limited liability companies, partnerships and trusts - has two core functions. First, organizational law supplies a set of contractarian rules, some of a fiduciary character, that provide for the internal governance or administration of the organization. These are the rules that provide for the powers and duties of the managers and the rights of the beneficial owners.

Second, organizational law supplies a set of proprietary rules that provide for asset partitioning or ring-fencing or entity shielding. These are the rules that provide for the separation of the property of the organization from the property of the organization's managers, beneficial owners and other insiders. Asset partitioning requires rules of agency to establish the authority of the managers to bind the organization in dealings with third parties, and rules of court procedure to establish the ability of the organization and third parties to sue each other.

Reconciliation of the contractarian governance and proprietary asset partitioning features of trust law is the theme that ties together the chapters for this volume by Thomas P. Gallanis and by Rebecca Lee. ${ }^{1}$

The author thanks Joshua Getzler, Henry Hansmann, Daniel Kleinberger, Reinier Kraakman and John Langbein for helpful comments and suggestions, and Greg Dihlmann-Malzer, Ronnie Gosselin and Jeffrey Hughes for excellent research assistance. Portions of this chapter derive from R. H. Sitkoff, 'The Economic Structure of Fiduciary Law' (2011) 91 Boston University Law Review 1039. In accordance with Harvard Law School's policy on conflicts of interest, the author discloses certain outside activities, one or more of which may relate to the subject matter of this chapter, at http://www.law.harvard.edu/faculty/COI/2012_Sitkoff_Robert.html.

${ }^{1}$ T. P. Gallanis, 'The Contribution of Fiduciary Law', Chapter 16 in this volume; R. Lee, 'Convergence and Divergence in the Worlds of the Trust: Duties and Liabilities of Trustees under the Chinese Trust', Chapter 17 in this volume. 
Gallanis argues for the importance of the governance features of trust law, chiefly trust fiduciary law. He frames his argument as a reply to scholars of organizational law whom he believes have mistakenly emphasized the significance of trust law's asset partitioning features and unfairly disparaged the importance of trust fiduciary law. Gallanis argues that trust fiduciary law is as important as its asset partitioning rules, and that Anglo-American trust fiduciary law provides a suitable template for civilian jurisdictions that are assimilating the trust concept.

Lee treats the Chinese enactment in 2001 of a systematic law of trusts as a natural experiment on the nature and function of trusteeship. Because China follows the civilian tradition of indivisible property ownership, the assimilation of Anglo-American trust law into Chinese law required replicating trust law's governance and asset partitioning functions without the express bifurcation of legal and beneficial ownership that is characteristic of the common law trust. Lee's thesis is that the Chinese law of trusts therefore provides a window on the essential characteristics of trusteeship.

The remainder of this essay, a commentary on the Gallanis and Lee chapters from an American perspective, is organized as follows. Part II develops further the idea that, the lack of juridical personality notwithstanding, trust law follows the governance and asset partitioning pattern of organizational law. Part III comments on the Gallanis essay. Part IV comments on the Lee essay. Part V concludes. The underlying theme of this essay is that trust law is not a species of property law or contract law, but rather is a species of organizational law.

\section{Trust law as organizational law}

The hallmark characteristic of the common law trust is bifurcation: the trustee holds legal title to the trust property and the beneficiaries have the equitable, or beneficial, interests. Two categories of issues arise from this splitting of legal and equitable ownership: (1) the powers and duties of the trustee and the corresponding rights of the beneficiary with respect to the trust property and against the trustee (governance), and (2) the effect on the rights of third parties with respect to the trust property versus the personal property of the trustee (asset partitioning). These issues - governance and asset partitioning - are together the core domain of organizational law. ${ }^{2}$

2 See, e.g., R. H. Sitkoff, 'An Agency Costs Theory of Trust Law' (2004) 89 Cornell Law Review 621, 624-34. 


\section{A. Fiduciary governance: powers and duties}

The underlying purpose of governance rules is to enable an organization's managers to act expeditiously on behalf of the organization and its beneficial owners while minimizing the agency costs arising from the separation of management and beneficial ownership. ${ }^{3}$ In the context of trust governance, the focus is on safeguarding the beneficiary's interest from mismanagement or misappropriation by the trustee in circumstances in which the trustee must have discretionary powers of administration.

The traditional but now outmoded governance strategy for protecting the beneficiary's interests was to negate the agency problem by disempowering the trustee. Under traditional law, the trustee had no default powers to engage in market transactions over the trust property. The trustee's powers were limited to those granted expressly in the trust instrument. The problem with this disempowerment strategy is that in protecting the beneficiary from mis- or malfeasance by the trustee, the law also disabled the trustee from undertaking transactions useful for the beneficiary.

As trusts have come increasingly to be funded with liquid financial assets that require alert management in the face of swiftly changing financial markets, modern trust law has come to give the trustee broad powers to undertake any type of transaction, subject to the trustee's fiduciary duties. ${ }^{4}$ Modern law gives the trustee 'all of the powers over trust property that a legally competent, unmarried individual has with respect to individually owned property'. ${ }^{5}$ However, 'in deciding whether and how to exercise the powers of the trusteeship, [the trustee] is subject to and must act in accordance with the [trustee's] fiduciary duties'.

What has happened, in other words, is that modern trust law has come to substitute empowerment subject to fiduciary obligation for simple disempowerment as the preferred means for safeguarding the beneficiary's interests. The settlor need not spell out with specificity what the trustee should do in all possible future circumstances, an impossible task given transaction costs and the settlor's lack of clairvoyance. Instead, trust law

3 Ibid., 627-48; see also R. H. Sitkoff, 'The Economic Structure of Fiduciary Law' (2011) 91 Boston University Law Review 1039, 1040-5.

${ }^{4}$ This thematic observation has been sounded most prominently by John Langbein. See J. H. Langbein, 'The Contractarian Basis of the Law of Trusts' (1995) 105 Yale Law Journal 625, 640-3; J. H. Langbein, 'Rise of the Management Trust' (October 2004) Trusts \& Estates 52.

${ }^{5}$ Restatement (Third) of Trusts, 4 vols. (St Paul: American Law Institute, 2003-12), $\$ 85(1)(a)$; see also Uniform Trust Code $\$ 815(a)(2)(A)(2000)$ [UTC].

${ }^{6}$ Restatement (Third) of Trusts, ibid., \$86; see also $\$ 70$, cmts. a, d. 
provides the trustee with expansive default powers of administration, the trustee's exercise of which is subject to review ex post for compliance with the open-ended fiduciary duties of loyalty and prudence. ${ }^{7}$

The fiduciary obligation thus minimizes transaction costs. ${ }^{8}$ Instead of trying in advance to reduce to writing provisions for every future contingency, the parties need only address expressly those contingencies that are important and likely enough to warrant the transaction costs of express provision. For all other contingencies, the fiduciary obligation fills the gap. A similar evolutionary pattern toward empowerment subject to fiduciary governance is apparent in the modern law of agency, partnerships and corporations - all fields in which the agency problem arising from incomplete contracting in the separation of management and beneficial ownership is likewise prominent.

Viewed in this manner, the fiduciary governance strategy of modern law is intuitive. The functional core of fiduciary law is deterrence. ${ }^{9}$ The fiduciary is induced to act in the best interests of the beneficiary by the threat of after-the-fact liability for breach of the fiduciary standards of conduct. The core fiduciary duties are the duties of loyalty and prudence (or care). The duty of loyalty proscribes misappropriation and regulates conflicts of interest by requiring the fiduciary to act in the 'best' or even 'sole' interests of the principal. The duty of prudence or care prescribes the fiduciary's standard of care by establishing an objective 'prudence' or 'reasonableness' standard in which the meaning of prudence or reasonableness is informed by industry norms and practices.

Although the duties of loyalty and prudence are formulated in terms of open-ended standards, the normal accretive process of the common law has produced a rich body of interpretive authority on fiduciary matters. This mass of authority includes not only decades of case law, but also generations of treatises, restatements and statutory codifications. Such authority improves predictability and reduces decision costs by providing instructive guidance on what the otherwise expansive duties of loyalty and prudence require of the trustee in particular circumstances.

7 The Restatement characterizes this structure as 'a basic principle of trust administration', namely, that 'a trustee presumptively has comprehensive powers to manage the trust estate and otherwise to carry out the terms and purpose of the trust, but that all powers held in the capacity of trustee must be exercised, or not exercised, in accordance with the trustee's fiduciary obligations'. Restatement (Third) of Trusts, above, note $5, \$ 70$, cmt. a.

8 See Sitkoff, 'Economic Structure', above, note 3, 1040-1, 1044.

9 See F. H. Easterbrook and D. R. Fischel, 'Corporate Control Transactions' (1982) 91 Yale Law Journal 698, 702. 
Accumulated experience with recurring, common sets of facts and circumstances has also led to the development of subsidiary or implementing rules regarding the application of the duties of loyalty or prudence to those circumstances. The trust law no-further-inquiry rule (and its proliferating exceptions) is an example of such a rule. ${ }^{10}$ Other common examples from across the fiduciary fields are specific rules on disclosure, earmarking, record-keeping, competition with the principal, theft of the principal's opportunity, and commingling funds.

Operating in tandem, the broad duties of loyalty and prudence plus the specific subsidiary rules provide the decision costs advantage of rules and the error costs advantage of standards. ${ }^{11}$ The subsidiary or implementing rules simplify application of the fiduciary obligation to cases that fall within their terms. But if the trustee acts in a manner that is inimical to the beneficiary's interests yet does not fall within one or another subsidiary rule, the beneficiary may still invoke the broad, open-ended duties of loyalty and prudence. ${ }^{12}$

Most fiduciary obligations are default rules that yield to the contrary agreement of the parties. This is true not only in trust law but across the fiduciary fields. The default character of most fiduciary rules follows from the nature of fiduciary governance as a system of deterrence meant to reduce agency costs in circumstances in which the fiduciary must have broad discretion. If the parties specify what the fiduciary should do in a particular contingency, the default fiduciary standards of conduct no longer pertain with respect to that contingency. Even the fiduciary duty of loyalty is subject to modification. If the principal gives informed consent to certain self-dealing by the fiduciary, the rationale for the duty of loyalty's prophylactic rule against self-dealing falls away. In such circumstances, the fiduciary may engage in the specified self-dealing, provided that she acts in good faith and that the transaction is objectively fair and in the best interests of the principal. ${ }^{13}$

${ }^{10}$ See Restatement (Third) of Trusts, above, note 5, $\$ 78, \mathrm{cmts}$. b-d.

11 See, e.g., L. Kaplow, 'Rules Versus Standards: An Economic Analysis' (1992) 42 Duke Law Journal 557.

12 See Sitkoff, 'Agency Costs Theory', above, note 2, 682-3. I have elsewhere characterized this mode of legal governance as a 'standard tempered by presumptions', in comparison to a 'rule tempered by exceptions'. J. Dukeminier, R. H. Sitkoff and J. Lindgren, Wills, Trusts, and Estates, 8th edn (Frederick, MD: Aspen Publishers, 2009), pp. 386-7.

13 See, e.g., Restatement (Third) of Trusts, above, note 5, $\$ 78, \mathrm{cmts}$. c-d; Restatement (Third) of Agency, 2 vols. (St Paul: American Law Institute, 2006), \$8.06(1); Principles of Corporate Governance: Analysis and Recommendations, 2 vols. (St Paul: American Law Institute, 1994), $\$ 5.02$. 
To be sure, there is a mandatory core to fiduciary obligation that cannot be overridden by agreement. A fiduciary may not be authorized to act in bad faith. ${ }^{14}$ Even if the principal authorizes self-dealing, fiduciary law provides substantive and procedural safeguards. The fiduciary must always act in good faith and deal fairly with and for the principal, and the fiduciary must apprise the principal of the material facts in securing the principal's informed consent to a conflicted action or self-dealing transaction. ${ }^{15}$ But such mandatory rules are not a serious impediment to the parties' reasonable refinement of the fiduciary obligation to be applied in their fiduciary relationship. Rather the mandatory core of fiduciary law serves an internal protective or cautionary function and an external categorization function.

With respect to the internal protective or cautionary function, the mandatory core insulates fiduciary obligations that the law assumes would not be bargained away by a fully informed, sophisticated principal. True, in an individual case a particular principal might be fully informed and have good reason to want to bargain away something from the mandatory core. But such circumstances are infrequent enough that a prophylactic (if paternalistic) mandatory rule may be justified nonetheless, at least in the traditional fiduciary fields such as trust and agency, in which the principal is commonly not sophisticated and fully informed.

With respect to the external categorization function, the mandatory core addresses the need for clean lines of demarcation across forms of property holding to minimize third-party information costs and to protect third-party rights. This standardization function has been much discussed in the contemporary learning in property theory. ${ }^{16}$ On this view, the mandatory core of fiduciary law polices the line that differentiates a fiduciary relationship on the one hand from a fee simple or other such arrangement on the other. A person may give property to another person and authorize the other person to act whimsically with respect to

14 See, e.g., Restatement (Third) of Trusts, above, note 5, \$78, cmt. c(2); Restatement (Third) of Agency, above, note 13, \$8.06(1)(a), (2)(a); Uniform Power of Attorney Act $\$ 114(\mathrm{a})(2)$ (2006); UTC \$105(b)(2); see also J. H. Langbein, 'Mandatory Rules in the Law of Trusts' (2004) 98 Northwestern University Law Review 1105.

15 See, e.g., Restatement (Third) of Trusts, above, note 5, \$78, cmt. c(2) (2007); Restatement (Third) of Agency, above, note 13, \$8.06.

${ }^{16}$ See H. Hansmann and R. Kraakman, 'Property, Contract, and Verification: The Numerus Clausus Problem and the Divisibility of Rights' (2002) 31 Journal of Legal Studies S373; T. W. Merrill and H. E. Smith, 'Optimal Standardization in the Law of Property: The Numerus Clausus Principle' (2000) 110 Yale Law Journal 1; T. W. Merrill and H. E. Smith, 'The Property/Contract Interface' (2001) 101 Columbia Law Review 773; see also Sitkoff, 'Agency Costs Theory', above, note 2, 643. 
the property. But this mode of transfer is an absolute gift, and this mode of holding property is fee simple. ${ }^{17}$

In summary, the purpose of the governance rules of trust law is to facilitate expeditious management of the trust property while minimizing the agency costs arising from separating management (the trustee) and beneficial ownership (the beneficiary). To that end, modern law supplies an expansive set of default powers that enable the trustee 'to engage in every conceivable transaction that might wrest market advantage or enhance the value of trust assets'. ${ }^{18}$ However, modern law subjects the trustee's exercise or non-exercise of those powers to fiduciary duties of loyalty and prudence as well as a set of implementing fiduciary sub-rules. The fiduciary obligation consists generally of default rules that are alterable in the trust instrument, though there is a mandatory core that serves protective and categorization functions.

\section{B. Asset partitioning: toward entitization}

The core function of asset partitioning rules in organizational law is to separate the personal property and obligations of the organization's insiders from the property and obligations of the organization. ${ }^{19}$ Such separation reduces monitoring costs and facilitates productive transactions by making the organization itself a transactional party separate from its managers and beneficial owners. For example, a prospective

17 The Delaware Supreme Court has put the point thus: 'A trust in which there is no legally binding obligation on a trustee is a trust in name only and more in the nature of an absolute estate or fee simple grant of property': McNeil v. McNeil, 798 A.2d 503, 509 (2002); see also Armitage v. Nurse [1997] 2 All ER 705, [1998] Ch 241, 253 (Millett LJ) (' $\mathrm{t}]$ here is an irreducible core of obligations owed by the trustees to the beneficiaries and enforceable by them which is fundamental to the concept of a trust. If the beneficiaries have no rights enforceable against the trustees there are no trusts').

The categorization, third-party information costs explanation for the mandatory core is strongest as regards fiduciary relationships for which there is no public notice filing upon creation such as agency and common law trusts. The explanation is weaker as regards filing entities such as corporations and limited liability companies, because the public filing that brings the entity into existence also provides notice to third parties of the existence of the organization. For this reason, and because the parties in such contexts are more likely to be fully informed and sophisticated, the mandatory core for filing fiduciary entities is both less robust and more contentious than in agency and trust law. See Sitkoff, 'Economic Structure', above, note 3, 1047-8.

18 Langbein, 'Contractarian Basis', above, note 4, 641.

19 The seminal exposition is H. Hansmann and R. Kraakman, 'The Essential Role of Organizational Law' (2000) 110 Yale Law Journal 387. 
lender to the organization need examine the finances of the organization only, acting without regard to the solvency of the organization's managers or beneficial owners. ${ }^{20}$ To be effective, asset partitioning also requires rules of agency to establish the authority of the managers to bind the organization, and rules of procedure to establish the ability of the organization and its counterparties to sue each other. ${ }^{21}$

For an organization that enjoys juridical personality, such as the corporation, strong asset partitioning is uncomplicated. The organization's property is held in the name of the entity, the insiders' personal property is held in the name of each insider, and the parties' respective obligations follow accordingly. The fact of the organization and its separateness from its managers and beneficial owners is easily verifiable in the notice-filing records of the jurisdiction in which the entity was formed. There was a clean and obvious line between the personal property and obligations of Steve Jobs, on the one hand, and the property and obligations of Apple, the corporation for which he was the chief executive officer, on the other. Each could sue or be sued with regard to the separate property of each.

For a common law trust, such straightforward asset partitioning is not possible. Formally a trust is not a freestanding juridical entity but rather a relationship created by private agreement without a filing with the state. A trust cannot sue, be sued, hold property or transact in its own name. Instead, the trustee sues, is sued, holds property and transacts with respect to trust property in the trustee's fiduciary capacity as trustee. Both substantive and semantic consequences ensue.

As a substantive matter, because the trustee holds legal title to the trust property, under traditional law the trustee was personally liable for the debts and other obligations arising from ownership of the trust property. The trustee's personal liability was offset, however, by a right to indemnification out of the trust corpus. A plumber who repaired a broken toilet in a rental building held in trust could recover his fee from the trustee personally, but the trustee would then indemnify himself for the expense out of the trust fund. This clumsy and formalistic ritual,

20 Ibid., 399-405.

${ }^{21}$ For a clear discussion, see J. Armour, H. Hansmann and R. Kraakman, 'What is Corporate Law?' paras. 1.2.1, 7-8, in R. Kraakman et al. (eds.), The Anatomy of Corporate Law: A Comparative and Functional Approach, 2nd edn (Oxford University Press, 2009), pp. 6-9. 
which is codified in authorities as late as the Second Restatement of Trusts, published in 1959, served no functional purpose. ${ }^{22}$

Prevailing American trust law has since been revised to provide that a creditor of the trustee in the trustee's fiduciary capacity as such recovers directly from the trust fund without recourse against the trustee's personal property. ${ }^{23}$ Likewise, even though the trustee has legal title to the trust property, a personal creditor of the trustee has no recourse against the trust property. ${ }^{24}$ Accordingly, from the perspective of third parties (i.e. persons outside of the settlor-trustee-beneficiary triangle), modern law in effect splits the trustee into 'two distinct legal persons: a natural person contracting on behalf of himself, and an artificial person acting on behalf of the beneficiaries. ${ }^{25}$

As a semantic matter, Americans have come to reify the trust, referring to it as if it were an entity (e.g. 'an agent owes a duty to the trust ${ }^{26}$ ). When we do so, we are making use of a convenient shorthand for the more awkward locution of the trustee acting in his fiduciary capacity as trustee. ${ }^{27}$ This simplification accords with prevailing American trust doctrine, which gives the trust relationship strong entity-like asset partitioning. Because modern law sharply separates the property of the trustee personally from the property of the trust, the contemporary American trust is in function (though not in juridical form) an entity. Reifying the trust in expression is an embrace of substantive function over technical form.

Three features of the asset partitioning rules require further elaboration. First, such rules tend to have a mandatory character with respect to the preservation of third-party rights. Just as the governing organizational documents of a corporation, limited liability company or

22 See Restatement (Second) of Trusts (St Paul: American Law Institute, 1959), $\$ \$ 244,261-5$; see also A. W. Scott, W. F. Fratcher, and M. L. Ascher, Scott and Ascher on Trusts, 5th edn (New York: Aspen Publishers, 2006), \$\$26.1-26.7.

${ }^{23}$ See Restatement (Third) of Trusts, above, note 5, $\$ \$ 105-6$ (2012); UTC $\$ 1010$.

${ }^{24}$ See Restatement (Third) of Trusts, above, note 5, \$42, cmt. c (2003); UTC \$507.

25 Hansmann and Kraakman, 'Role of Organizational Law', above, note 19, 416; see also H. Hansmann and U. Mattei, 'The Functions of Trust Law: A Comparative Legal and Economic Analysis' (1998) 73 NYU Law Review 434. For a similar discussion rooted in the concept of a separate patrimony, see G. L. Gretton, 'Trusts Without Equity' (2000) 49 International \& Comparative Law Quarterly 599, 608-13.

${ }^{26}$ Uniform Prudent Investor Act $\$ 9$ (b) (1994); see also Restatement (Third) of Trusts, above, note $5, \$ 80$, cmt. g.

27 This discussion is thus a brief answer to Lionel Smith's criticism in 'Mistaking the Trust' (2010) 40 Hong Kong Law Journal 787, 799-800; see also L. Smith, 'Trust and Patrimony' (2008) 38 Revue générale de droit 379. 
partnership could not validly foreclose recovery against the organization's property by a third party in satisfaction of the third party's claim against the organization, ${ }^{28}$ a trust instrument cannot validly foreclose recovery against trust property by a third party in satisfaction of the third party's claims against the trust. ${ }^{29}$ Regardless of whether an organization has formal juridical personality, in creating what is in effect an artificial person separate from the organization's insiders, the law requires this artificial person to be responsible for claims against it by third parties.

Second, the effectiveness of the mandatory protection of third-party rights in the asset partitioning rules is in part dependent on the mandatory rules of fiduciary governance. Such mandatory rules serve a categorization or standardization function in the numerus clausus sense by providing notice and clean lines of demarcation across and within types of property holdings. ${ }^{30}$ Organizational property, which is always available to a creditor of the organization unless the creditor waives that right, ${ }^{31}$ must be earmarked and administered as such.

Third, unlike fiduciary governance, which is in theory (though not always in fact) replicable by contract, the asset partitioning of organizational law is categorically not replicable by contract. Persons cannot create a ring-fenced fund, protecting their personal assets against future claimants, by a web of contracts among themselves without also invoking the asset partitioning rules of trust or other organizational law. This insight, which has been developed most extensively by Henry Hansmann and Reinier Kraakman, ${ }^{32}$ reflects the inability to limit by contract the rights

${ }^{28}$ See, e.g., Revised Uniform Limited Liability Company Act $\$ 110(c)(1)$, (c)(11) (2006); Uniform Limited Partnership Act $\$ 110(\mathrm{~b})(1)$, (b)(13) (2001); Revised Uniform Partnership Act $\$ 103(b)(10)$ (1997). In the words of the official comment to Uniform Limited Partnership Act $\$ 110(\mathrm{~b})(13)$ : 'The partnership agreement is a contract, and this provision reflects a basic notion of contract law - namely, that a contract can directly restrict rights only of parties to the contract and of persons who derive their rights from the contract'.

29 See UTC $\$ 105(\mathrm{~b})(11)$.

30 See above, note 16 , and text accompanying.

31 An interesting encroachment on this principle is the rise of the series organization. For an example, see article 4 of the Uniform Statutory Trust Entity Act (2009).

32 The principal work is Hansmann and Kraakman, 'Role of Organizational Law', above note 19, previewed in H. Hansmann and R. Kraakman, 'Organizational Law as Asset Partitioning' (2000) 44 European Economic Review 807, and applied to trust law in Hansmann and Mattei, 'Functions of Trust Law', above, note 25. See also Armour et al., 'What is Corporate Law?', above, note 21, para. 1.2.1; H. Hansmann, R. Kraakman and R. Squire, 'Law and the Rise of the Firm' (2006) 119 Harvard Law Review 1333; H. Hansmann, R. Kraakman and R. Squire, 'The New Business Entities in Evolutionary 
of third parties not privy to the contract. By contrast, because fiduciary law creates rights and imposes duties only on the parties to the fiduciary relationship or their privies, there is no legal impediment to those parties replicating the applicable fiduciary rules by contract. This latter point is the premise of John Langbein's argument that, as regards the trustee's powers and the role of trust fiduciary law in governing the exercise of those powers, trust law is predominantly contractarian. ${ }^{33}$

To be sure, fiduciary law serves a crucial role in minimizing transaction costs. Without the ability to absorb an existing set of fiduciary governance rules tailored to the particulars of the agency problem in the undertaking the parties intend, the parties would need to think up and then spell out such rules in detail. In some circumstances, the associated transaction costs would be insuperable, suppressing otherwise beneficial deals. For those deals in which the transaction costs would otherwise be insuperable, fiduciary law is essential. This transaction costs minimizing function, in which the state supplies the public good of standard-form fiduciary contracts, has been discussed extensively in the literature, particularly of corporate law. ${ }^{34}$ Standard-form fiduciary contracts include agency, partnership, trust, corporation and limited liability company.

There is, however, a difference in kind between the utility of organizational law in reducing transaction costs by offering standard-form fiduciary contracts versus the necessity of organizational law to overcome the limited reach of contract law by offering asset partitioning as against third parties. Without the ability to absorb the default fiduciary governance rules of organizational law, the question in each prospective deal would be whether the parties had enough to gain from the deal to warrant incurring the costs of creating such rules from scratch by contract. Even if fiduciary law is in fact essential in a particular deal,

Perspective' (2005) University of Illinois Law Review 5; Hansmann and Kraakman, 'Property, Contract, and Verification', above, note 16. Hansmann and Kraakman previously questioned the necessity of corporate limited liability in tort. See H. Hansmann and R. Kraakman, 'Do the Capital Markets Compel Limited Liability? A Response to Professor Grundfest' (1992) 102 Yale Law Journal 427; H. Hansmann and R. Kraakman, 'A Procedural Focus on Unlimited Shareholder Liability' (1992) 106 Harvard Law Review 446; H. Hansmann and R. Kraakman, 'Toward Unlimited Shareholder Liability for Corporate Torts' (1991) 100 Yale Law Journal 1879.

33 See Langbein, 'Contractarian Basis', above, note 4.

${ }^{34}$ See, e.g., F. H. Easterbrook and D. R. Fischel, The Economic Structure of Corporate Law (Cambridge, MA: Harvard University Press, 1991), pp. 34-5; see also L. E. Ribstein, 'Making Sense of Entity Rationalization' (2003) 58 Business Lawyer 1023. 
fiduciary law is not essential as a matter of categorical legal necessity. There is no legal disability, as opposed to a transaction costs obstacle, to replicating the rules of trust or other fiduciary law by way of an ordinary contract.

By contrast, the asset partitioning rules of trust and other organizational law are categorically essential as a matter of legal necessity. The parties to a prospective deal cannot validly replicate the third-party effects of organizational law's asset partitioning rules by way of ordinary contracts. Without organizational law, one cannot create a ring-fenced fund of certain property that is enforceable against third parties. It is in this sense that Hansmann and Kraakman and other scholars of organizational law speak of the 'essential role of organizational law'. ${ }^{35}$ No one denies the utility of trust law and other species of organizational law as 'standard-form contracts among the parties who participate in an enterprise'. ${ }^{36}$ Rather, the claim is that the 'essential' role of organizational law is 'the creation of relationships that could not practicably be formed by contract alone'. ${ }^{37}$

In summary, the core function of asset partitioning rules in organizational law is to separate the personal property and obligations of the organization's insiders from the property and obligations of the organization. Such separation reduces monitoring costs and facilitates productive transactions by creating a separate counterparty for deals pertaining to the organization's property. In the context of trust law, asset partitioning allows the trustee to deal separately with his personal creditors and with creditors in respect of trust property. ${ }^{38}$ Because prevailing modern American trust law gives creditors of the trust (i.e. creditors of the trustee in his fiduciary capacity as such) direct recourse against the trust property and no rights against the trustee's personal property, the modern American trust is in function (though not in form) an entity separate from the trustee and the beneficiary. Unlike the rules of fiduciary governance, which could in theory be replicated by contract subject only to the constraint of transaction costs, the rules of asset partitioning, which reorganize the rights of third parties to the trust property, could not likewise be replicated by an ordinary contract owing to the inability of a contract to limit the rights of non-privies.

35 Hansmann and Kraakman, 'Role of Organizational Law', above, note 19.

36 Ibid., 390. ${ }^{37}$ Ibid. $\quad{ }^{38}$ See Sitkoff, 'Agency Costs Theory', above, note 2, 631-3. 


\section{Gallanis and the contribution of fiduciary law}

In his chapter in this volume, Thomas Gallanis undertakes to identify what Anglo-American trust law might usefully contribute to other legal systems. From this point of departure, Gallanis argues for the importance of trust fiduciary law. Gallanis's underlying purpose is to urge the suitability of Anglo-American trust fiduciary law as a model for jurisdictions that seek to assimilate the trust concept. To this end, Gallanis advances two claims. First, to establish the significance of trust fiduciary law, he argues against what he perceives to be a mistaken analysis by scholars of organizational law who emphasize the significance of trust law's asset partitioning features and, in Gallanis's view, needlessly 'downplay $^{39}$ the important contribution of trust fiduciary law. Second, having established the importance of trust fiduciary law by rebutting those who he thinks have challenged its importance, Gallanis points to the development of trust law in France and China as illustrations of the potential for Anglo-American trust fiduciary law to serve as a model for jurisdictions lacking indigenous trust law.

\section{A. Fiduciary law and asset partitioning}

Gallanis's overarching claim is that trust fiduciary law makes an important welfare contribution. He does not advance this claim with a theoretical or empirical model, however. Instead he makes his affirmative case for the significance of fiduciary law by way of a critical discussion of recent work in the literature of organizational law as applied to trust law. According to Gallanis, this work has mistakenly identified asset partitioning as the essential contribution of trust law and wrongly disparaged the contribution of fiduciary law as 'relatively unimportant'.

Gallanis takes as his foil a paper published in 1998 by Henry Hansmann and Ugo Mattei. ${ }^{41}$ That paper is an early writing in what is now a more mature corpus on asset partitioning by Hansmann and various co-authors, principally Reinier Kraakman. ${ }^{42}$ The underlying

${ }^{39}$ Gallanis, 'The Contribution of Fiduciary Law', Chapter 16 in this volume, p. 397.

${ }^{40}$ Ibid., p. 390.

${ }^{41}$ See Hansmann and Mattei, 'Functions of Trust Law', above, note 25. Hansmann and Mattei published an abridged version of this paper as H. Hansmann and U. Mattei, 'Trust Law in the United States: A Basic Study of Its Special Contribution' (1998) 46 American Journal of Comparative Law 133.

${ }^{42}$ See above, note 32 . 
thesis of this body of work is that unlike fiduciary governance, which does not affect the rights of third parties and hence in theory could be replicated by contract, asset partitioning rules reorganize the rights of third parties and therefore could not be replicated by contract. On this view, the essential contribution of organizational law is asset partitioning, with the term 'essential' used to describe that which is categorically impossible without organizational law.

Gallanis is 'troubled' by Hansmann and Mattei's analysis. ${ }^{43}$ His discontent is rooted in the observations that fiduciary law includes mandatory as well as default rules; that some fiduciary rules are penalty defaults rather than majoritarian or market-mimicking defaults; and that the nuance and complexity of the web of rules and standards that comprise trust fiduciary law resist easy (read: low-transaction-cost) replication by private agreement.

These observations and Gallanis's broader claim that fiduciary law makes a significant contribution are surely correct. But I don't see how these points, with which I am certain Hansmann and his collaborators would agree, undermine their claim of the categorical necessity of organizational law to achieve asset partitioning. The Hansmann and Mattei paper should be read in the context of the subsequent asset partitioning literature that has elaborated on the theory, ${ }^{44}$ and against the transaction costs fiduciary law literature that the asset partitioning work was meant to enrich. ${ }^{45}$ Contextualized in this way, it seems evident that the aim of the project by Hansmann and his collaborators was to identify the essential core of organizational law that could not ever, even with an assumption of zero transaction costs, be replicated by way of contract or other law. ${ }^{46}$ Accordingly, no language in those papers should be read to imply that the authors believe that fiduciary law lacks real-world significance.

Start with the point that fiduciary law includes mandatory as well as default rules. As Gallanis acknowledges, Hansmann and his collaborators do not deny that fiduciary law includes mandatory rules or that the mandatory character of such rules serves useful policies. ${ }^{47}$ Rather their point is that whatever the rules of governance supplied by fiduciary law, whether those rules are default or mandatory, in theory such rules could be replicated in a contract binding on those privy to the contract.

${ }^{43}$ Gallanis, 'Contribution of Fiduciary Law', Chapter 16 in this volume, p. 392.

${ }^{44}$ See above, note 32. $\quad{ }^{45}$ See text accompanying, above, note 34 and, below, note 60 .

46 See Hansmann and Kraakman, 'Role of Organizational Law', above, note 19, 437.

47 Ibid., 437-8, 440. 
A similar answer can be given to the point that some fiduciary rules are penalty defaults. Because such rules are meant to induce explicit contracting, perforce there is no legal impediment to the parties replicating the outcome of that negotiation by way of a contract rather than a trust agreement. $^{48}$ True, without the fiduciary law superstructure the information-forcing benefit would be lost. But this is to say that the structure of fiduciary law usefully alters the negotiation dynamic in setting the terms of the parties' contract, ${ }^{49}$ not that private contract is categorically impossible.

This brings us to the most substantial issue - transaction costs. To illustrate the point that trust fiduciary law could be replicated by contract, Hansmann and Mattei suggested that a prospective settlor and a prospective trustee could execute a contract containing the relevant sections of the Restatement of Trusts. ${ }^{50}$ Such a contract would be valid, providing for powers and duties perfectly tracking those of trust law, both default and mandatory. By contrast, the asset partitioning effect of trust law, good against third parties not privy to the contract, could not likewise be replicated. In this sense the asset partitioning effect of trust law, but not the law of powers and duties, is essential.

Gallanis's answer to the Restatement-incorporation heuristic, a thought experiment, is to say that it is 'extremely unrealistic'. ${ }^{51}$ Gallanis explains: 'While a settlor and prospective trustee could agree to the current rules of trust fiduciary law, they are extremely unlikely to do so. ${ }^{, 52}$ This critique reflects a mistaken view of the project of Hansmann and his collaborators. Their core claim, with which Gallanis appears to agree, is that no rule of contract law (as compared to preferences or transaction costs) would interfere with a prospective settlor and a prospective trustee entering into a valid contract reproducing the entirety of the current Restatement of Trusts and providing that those provisions are to be interpreted in accord with the prevailing interpretation of the Restatement. Such a contract would, by force of contract law, create among the putative settlor, trustee and beneficiary the same rights, powers and duties as under trust law - but there would be no third-party

48 Ibid., 437 (discussing rules that put the parties on notice of non-standard governance provisions).

49 See Sitkoff, 'Economic Structure', above, note 3, 1049.

${ }^{50}$ See Hansmann and Mattei, 'Functions of Trust Law', above, note 25, 447-8.

${ }^{51}$ Gallanis, 'Contribution of Fiduciary Law', Chapter 16 in this volume, p. 395.

52 Ibid. 
asset partitioning. ${ }^{53}$ The Restatement-incorporation thought experiment thus brings into sharp relief the categorical impossibility of achieving asset partitioning without organizational law.

Gallanis's real point, I think, is that even if fiduciary law pertains only within the settlor-trustee-beneficiary triangle, such law makes important contributions by protecting the unsophisticated (read: mandatory rules); by altering the negotiating dynamic (read: penalty defaults); and, perhaps most importantly, by reducing transaction costs (read: no need to dicker over expensive, nuanced and complex rules). As is made clear in their subsequent work, Hansmann and his collaborators agree. In the centrepiece paper of this line of work, Hansmann and Kraakman argue that 'aspects of organizational law other than asset partitioning are not "essential" in the sense that workable substitutes for them [exist] elsewhere in the law. This is not to say, however, that elements of organizational law other than asset partitioning are trivial and could be dispensed with costlessly'. ${ }^{54}$ To the contrary, the 'efficiencies offered by the various detailed rules governing standard-form legal entities are important'. ${ }^{55}$ Nevertheless, asset partitioning is the only important feature of [organizational law] for which substitutes could not be crafted, at any price that is even remotely conceivable, using just the basic tools of contract, property, and agency law'. ${ }^{56}$

Reworking Gallanis's critique of Hansmann and Mattei into an explanation of trust fiduciary law rooted in transaction costs reconciles Gallanis's disagreement with Hansmann and his collaborators and makes clearer the sensible core thesis of Gallanis's essay. The cleavage between Gallanis and the asset partitioning literature is not in the fact of transaction costs in replicating fiduciary law by private agreement, but rather in the magnitude of the costs involved in doing so. Hansmann and his coauthors regard the contribution of organizational law in minimizing such costs as being 'not of the same order ${ }^{57}$ as the contribution of

53 The beneficiary would become that species of contract party called a third-party donee beneficiary. See Restatement (Second) of Contracts (St Paul: American Law Institute, 1981), $\$ 302$, cmt. c.

${ }^{54}$ Hansmann and Kraakman, 'Role of Organizational Law', above, note 19, 437.

${ }^{55}$ In a subsequent writing, Hansmann suggested that the ability of the legislature simultaneously to modify the governance of all firms making use of one or another form of entity is yet another cost saving from state-supplied standard-form entities. See H. Hansmann, 'Corporation and Contract' (2006) 8 American Law \& Economics Review 1.

${ }^{56}$ Hansmann and Kraakman, 'Role of Organizational Law', above, note 19, 437.

57 Ibid. 
organizational law in providing for asset partitioning. In response, Gallanis says that Hansmann and Mattei's 'estimates of transaction costs sometimes have the air of ipse dixit ${ }^{58}$ To illustrate, he points to the expansive and discursive fiduciary provisions of the 2007 volume of the Third Restatement of Trusts. Given the breadth and depth of those provisions, Gallanis suggests that 'the negotiation between a settlor and a prospective trustee about all of these rules' might well be 'complex and costly. ${ }^{59}$

Viewed in this manner, Gallanis has undertaken to rehabilitate the prior generation of fiduciary contractarians, most obviously Frank Easterbrook and Daniel Fischel, who argued that the primary function of organizational law is to minimize transaction costs by providing a menu of standard-form fiduciary contracts. ${ }^{60}$ Unlike Easterbrook and Fischel, Gallanis does not state expressly that fiduciary terms are 'public goods' that warrant public provision. ${ }^{61}$ But his argument about the transaction costs of replicating by private agreement the nuances of fiduciary law maps onto the Easterbrook and Fischel analysis quite neatly.

The affirmative case for the importance of trust fiduciary law should not rest on a critical analysis of Hansmann and Mattei, but rather on a functional explanation of the purpose of fiduciary law - that is, minimizing transaction costs in establishing terms that will suppress agency costs. $^{62}$ For persons wishing to create a trust, the existence of trust fiduciary law provides a ready-made web of rules and standards to govern the trustee's exercise of the trustee's discretionary powers of administration. This web of rules includes a few that are mandatory, with protective and categorical purposes, and a few that are penalty defaults, to encourage disclosure and precise articulation of intention. But otherwise the rules are market-mimicking defaults, which economizes on transaction costs. Overall, trust fiduciary governance provides for expeditious management of the trust property while minimizing the agency costs arising from separating management (the trustee) and beneficial ownership (the beneficiary).

\footnotetext{
${ }^{58}$ Gallanis, 'Contribution of Fiduciary Law', Chapter 16 in this volume, p. 394.

59 Ibid., p. 395.

${ }^{60}$ See Easterbrook and Fischel, Economic Structure of Corporate Law, above, note 34, pp. $34-5$.

61 Ibid., p. 35 .

${ }^{62}$ See above, notes 3, 8 and 34, and text accompanying.
} 


\section{B. Exporting fiduciary law abroad}

Having undertaken to establish the importance of trust fiduciary law, Gallanis points to the development of trust law in China and France as illustrations of the potential for Anglo-American trust fiduciary law to serve as a template for foreign jurisdictions interested in assimilating the trust concept. Gallanis's treatment is largely descriptive. He starts with China and then moves to France.

The Chinese trust law, an adaptation of the common law trust for the Chinese civilian system, includes many fiduciary rules that closely resemble those of Anglo-American law. Gallanis schedules a host of examples and explains that the similarity is deliberate. Gallanis also remarks upon several differences, chiefly in the trustee's duties to the settlor, delegation by the trustee, and in impartiality among concurrent beneficiaries without provision for impartiality when administering successive beneficial interests. Gallanis points to the Chinese tradition of undivided ownership in explanation for the focus on concurrent rather than successive interests. But Gallanis does not say clearly whether the terms of the trust can provide for successive interests and modify the duty of impartiality accordingly.

Gallanis celebrates the similarities between Chinese trust law and Anglo-American trust fiduciary law. To Gallanis, the similarities evidence how 'well-developed and sophisticated, and suited to modern legal practice', is trust fiduciary law. ${ }^{63}$ Here it is noteworthy that Hansmann and his collaborators agree. In the centrepiece paper of the asset partitioning corpus, Hansmann and Kraakman took notice of 'the fact that most developed market economies provide for standard-form legal entities that are similar in their basic features'. ${ }^{64}$ To Hansmann and Kraakman, like Gallanis, this fact is evidence that the governance rules of organizational law provide real-world benefits such as economizing on transaction costs.

A more interesting question is how to explain the differences between Anglo-American and Chinese trust law. A common observation in the economic literature on fiduciary law is that the precise contours of the fiduciary obligation vary across fiduciary applications. ${ }^{65}$ This observation about the doctrine fits nicely the agency and transaction costs theory of fiduciary law, in which the fiduciary obligation operates as an after-the-

${ }^{63}$ Gallanis, 'Contribution of Fiduciary Law', Chapter 16 in this volume, p. 402.

${ }^{64}$ Hansmann and Kraakman, 'Role of Organizational Law', above, note 19, 437.

65 See Sitkoff, 'Economic Structure', above, note 3, 1045. 
fact completion of what is necessarily an incomplete contract, ${ }^{66}$ because agency problems vary across contexts. For example, the fiduciary obligation in American trust law is generally stricter than the fiduciary obligation in American corporate law. But those differences reflect the different contexts. The agency problem in a family trust in which the beneficiaries have no exit option and that is managed by a corporate fiduciary that cannot easily be replaced differs significantly from the agency problem in a large, publicly traded corporation from which a shareholder can separate easily by selling his shares in a thick securities market (the 'Wall Street rule'). ${ }^{67}$

So a pressing question, not addressed in Gallanis's discussion (but elsewhere discussed by Frances Foster ${ }^{68}$ ), is why the Chinese authorities opted to deviate in certain respects from the Anglo-American model. Do those deviations reflect material differences in the underlying agency structure of the Chinese trust? Are such trusts predominantly managed by professional fiduciaries? Is the Chinese system of adjudication more or less reliable than the Anglo-American courts? The fact of the settlor's enforcement right and the absence of successive interests, for example, would seem to bear on the nature and scope of the agency problem to be ameliorated by the Chinese fiduciary law.

Gallanis's treatment of the French trust fiduciary law is more functional. According to Gallanis, the French counterpart to the Anglo-American trust, the fiducie, is meant for commercial purposes, not donative wealth transfer. To Gallanis, the fiducie thus has a narrower purpose than the Anglo-American trust, and this explains why its accompanying fiduciary law is less detailed. But French lawyers have begun to urge that the fiducie be used in family wealth transfer. If this idea comes to fruition, Gallanis argues, then Anglo-American trust fiduciary law could provide a useful template for expanding French fiduciary law accordingly.

The underlying insight is that Anglo-American trust fiduciary law evolved out of long experience with the agency costs that arise in separating management and beneficial ownership in a donative transfer 'projected on the plane of time'. ${ }^{69}$ Gallanis's point, which seems quite

${ }^{66}$ F. H. Easterbrook and D. R. Fischel, 'Contract and Fiduciary Duty' (1993) 36 Journal of Law \& Economics 425, 432-4.

67 See R. H. Sitkoff, 'Trust Law, Corporate Law, and Capital Market Efficiency' (2003) 28 Journal of Corporation Law 565; see also S. M. Bainbridge, 'The Case for Limited Shareholder Voting Rights' (2006) 53 UCLA Law Review 601, 619.

68 See F. H. Foster, 'American Trust Law in a Chinese Mirror' (2010) 94 Minnesota Law Review 602, 621-50.

${ }^{69}$ B. Rudden, 'Book Review' (1981) 44 Modern Law Review 610, 610. 
sensible, is that if the French are to make use of a transactional structure for which we have centuries of experience, they would do well to examine the governance regime we developed out of that experience.

But Gallanis's focus on critiquing Hansmann and Mattei obscures deeper questions. What are the commercial purposes to which the French trust is put? Why hasn't the agency problem in those applications already strained 'the thin fiduciary rules in French law'? ? $^{70}$ American corporate law, used routinely in commercial transactions, has a rather detailed fiduciary law, including extensive rules on corporate opportunities, executive compensation and ratification of conflicted transactions. ${ }^{71}$ If agency costs in the commercial applications of the fiducie have been minimized other than with fiduciary law, perhaps the same techniques would be available in a donative application? Gallanis takes as a given that commercial applications do not require much fiduciary law, but this assumption does not follow from an immutable rule of organizational dynamics.

Gallanis's discussion of the function of fiduciary law is stimulating and generative, and in my view largely sound. His discussion of Chinese and French trust law is interesting and also impressive inasmuch as neither jurisdiction uses English as its primary language. But Gallanis's organizing motivation, critiquing Hansmann and Mattei, needlessly distracts from the deeper issues to which his chapter points and from his sensible core thesis that trust fiduciary law improves social welfare by minimizing transaction costs.

\section{Lee and the transplantation of trust law}

In her chapter for this volume, Rebecca Lee takes the Chinese enactment in 2001 of a systematic law of trusts as a natural experiment on the nature and function of trusteeship. Because China follows the civilian tradition of indivisible ownership, the Chinese assimilation of Anglo-American trust law required replicating trust law's governance and asset partitioning features without an express bifurcation of legal and beneficial ownership. The idea that animates Lee's essay is that the resulting Chinese law of trusts provides a window on the essential characteristics of trusteeship. Lee's thesis is that, to the extent the Chinese law

${ }^{70}$ Gallanis, 'Contribution of Fiduciary Law', Chapter 16 in this volume, p. 404.

${ }^{71}$ See, e.g., Principles of Corporate Governance: Analysis and Recommendations, above, note 13, $\$ 4.01-6.02$ (1992). 
replicates the functional structure of the Anglo-American trust without bifurcating legal and equitable ownership, such bifurcation is not an essential feature of the trust.

Lee begins her analysis with the fascinating revelation that the creation of a Chinese trust does not require a transfer of property to the trustee. Instead, the settlor retains formal ownership of the property but entrusts the management of the property to the trustee, subject to fiduciary obligations that run to the beneficiaries and the settlor. The trustee might take custodial possession of the trust property, but the settlor remains the owner. In this respect, the arrangement resembles common law agency, which likewise provides fiduciary governance without reorganizing ownership rights.

But the Chinese trust does reorganize ownership rights. Upon creation of a Chinese trust, the settlor must separate the trust property from the rest of his personal property. Crucially, this separateness is good against third parties, or at least against the trustee's personal creditors (more on this qualification later). To this extent, the Chinese trust is indeed a functional replication of the Anglo-American trust. The Chinese trust provides fiduciary management of identified property (the governance function) that is separated from the personal property of the trustee even against third parties (the asset partitioning function). The Chinese trust is an organization; the Chinese law of trusts is organizational law.

To reconcile the Chinese trust's deviance from the Anglo-American requirement of a predicate conveyance of legal title to the trustee, Lee conceptualizes trusteeship as an office in which the holder of the office has management powers subject to fiduciary obligation. On this view, ${ }^{72}$ the Anglo-American bifurcation of legal and equitable title is a convenient but inessential mechanism to that end. The core internal feature of the trust is the separation of the management of the trust property from the beneficial interest in that property, subject to a governance regime

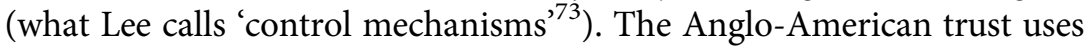
the artifice of legal and equitable ownership not because the separation of law and equity is categorically necessary, but because of the ready accessibility of those concepts in the English legal tradition.

72 Suggested, for example, by Tony Honoré. See T. Honoré, 'On Fitting Trusts into Civil Law Jurisdictions' (http://users.ox.ac.uk/ alls0079/chinatrusts2.PDF) 6; see also Sitkoff, 'Agency Costs Theory', above, note 2, 641-3; Gretton, 'Trusts Without Equity', above, note $25,617-18$.

${ }^{73}$ Lee, 'Convergence and Divergence', Chapter 17 in this volume, passim. 
In a jurisdiction such as China, which lacks the Anglo-American tradition of separate law and equity courts, the separation of management and beneficial interest can be achieved through contractual imposition of a governance regime that parallels the rights, powers and duties of AngloAmerican trust law. In this sense, the Chinese experience is something of a natural experiment on Langbein's analogy of the Anglo-American trust to a third-party-beneficiary contract and Hansmann and his collaborator's argument that contract or contract-plus-agency is enough to replicate the trust's internal governance. ${ }^{74}$ Lee makes a compelling argument that the Chinese trust captures the basic fiduciary governance regime of the AngloAmerican trust without the contortions of separate legal and equitable ownership. As regards internal governance, the Chinese trust is thus a victory for the contractarian model of trust fiduciary governance.

To be sure, Lee identifies areas in which, to her way of thinking, the Chinese trust governance regime is lacking and could be improved. She would like to clarify the information rights of the beneficiary. She would also like more certainty on the permissible scope of exoneration clauses, such as in the Uniform Trust Code, now in force in about half the American states. ${ }^{75}$ But these details are more in the nature of plumbing than architecture. The familiar trust architecture of powers subject to after-the-fact scrutiny for compliance with fiduciary standards of conduct is evident. ${ }^{76}$ And in Lee's telling, that structure was produced by way of a contractarian theory.

Yet the role of the Chinese settlor presents a puzzle. According to Lee, the settlor can control the trustee's management of the trust property, and the beneficiary has no rights against the settlor. Lee sees this reserved power in the settlor as being in tension with the English conception that, ultimately, the trust property belongs to the beneficiary. In the English tradition, illustrated by Saunders v. Vautier, ${ }^{77}$ the settlor relinquishes his rights in the trust property, and 'the dead hand continues to rule only by sufferance of the beneficiar[ies]. ${ }^{78}$ Without an express reservation of rights, the settlor has no continuing interest in the trust property. ${ }^{79}$

${ }^{74}$ See Langbein, 'Contractarian Basis', above, note 4; Hansmann and Mattei, 'Functions of Trust Law', above, note 25; Hansmann and Kraakman, 'Role of Organizational Law', above, note 19.

75 See UTC $\$ 1008$.

77 (1841) Cr. \& Ph. 240, 41 E.R. 482 (Ch.).

${ }^{78}$ See Sitkoff, 'Agency Costs Theory', above, note 2, 662-3.

79 See P. Matthews, 'The Comparative Importance of the Rule in Saunders v. Vautier' (2006) 122 Law Quarterly Review 266. 
But the English view does not follow inexorably from immutable first principles of trust law. In the American tradition, illustrated by Claflin v. Claflin $^{80}$ and by the recognition of spendthrift trusts, ${ }^{81}$ the trust is a conditional gift. The beneficiary takes his interest in the trust subject to any restrictions imposed by the settlor. Constrained only by antidead-hand public policy rules such as the rule against perpetuities and the rule against capricious purposes, the American settlor is free to impose conditions on the beneficiary's enjoyment of the trust property. ${ }^{82}$ Viewed in this manner, the puzzle is not so much that the Chinese give the settlor standing to enforce the trust, but rather the American reluctance, outside of recent reform in trustee removal and in charitable trusts, to do the same. ${ }^{83}$ As Langbein has suggested, settlor standing is consistent with a contractarian understanding of trust governance, ${ }^{84}$ a point I have elaborated on elsewhere from an agency costs perspective. ${ }^{85}$

In Lee's telling, however, the settlor has more than an enforcement right akin to the rights of a party to a third-party beneficiary contract. The settlor is also granted other extensive powers to intervene in the trustee's management of the trust property, including the power to manage the trust property, and even the right to request the trustee to adjust the methods of management' ${ }^{86}$ To an American trust lawyer, this passage evokes the contemporary revocable trust, which has come to be conceptualized in American practice as a will substitute for posthumous transfer outside of the probate system. Under modern American trust law, the trustee of a revocable trust is subject to the control of the settlor, and the trustee's fiduciary duties run only to the settlor, for so long as the settlor retains the power of revocation. ${ }^{87}$

The analogy to the revocable trust is imperfect. Nothing in Lee's discussion implies that the Chinese trust was meant to be a will substitute. Even so, the analogy brings into focus the need to get a grip on the purpose and uses of the Chinese trust. American trust law has fractured

8020 N.E. 454 (Mass. 1889).

81 Compare Dukeminier, Sitkoff and Lindgren, Wills, Trusts, and Estates, above, note 12, pp. 614-16, with Brandon v. Robinson, (1811) 18 Ves. Jr. 429, 34 E.R. 379 (Ch.).

82 See Restatement (Third) of Property: Wills and Other Donative Transfers, 3 vols. (St Paul: American Law Institute, 1999-2011), \$10.1, cmt. c.

83 See Restatement (Third) of Trusts, above, note 5, \$94; UTC \$\$706(a), 405(c).

84 Langbein, 'Contractrian Basis', above, note 4, 664.

85 Sitkoff, 'Agency Costs Theory', above, note 2, 666-9.

86 Lee, 'Convergence and Divergence', Chapter 17 in this volume, p. 417.

87 See Restatement (Third) of Trusts, above, note 5, \$74; UTC \$603(a). 
into three distinct branches: (1) business trusts, now dominated by the Delaware statutory business trust, a juridical entity with capacity to sue, be sued, and hold property in its own name; ${ }^{88}$ (2) revocable trusts, a will substitute over which the settlor remains in control and in which the beneficiary has no rights; and (3) irrevocable trusts, the traditional trust in which a segregated pool of assets is held by a trustee subject to a fiduciary governance regime for the benefit of one or more beneficiaries. ${ }^{89}$ Lee's discussion, in particular her worry about the lack of clarity in the Chinese law respecting exoneration clauses, implies that the Chinese trust is not a will substitute but rather a business trust or a donative irrevocable trust.

The revocable trust analogy also points to the question of whether the settlor's creditors have recourse against the trust property as in the American revocable trust. ${ }^{90}$ The American rule follows from the role of the revocable trust as a will substitute; in truth, in a revocable trust the trust property still belongs to the settlor. Lee's discussion, including her reference to a 'separate trust patrimony' and the rules requiring the settlor to segregate the trust property, ${ }^{91}$ implies that the settlor's creditors cannot reach the trust property. But Lee does not address this issue expressly. Instead, following Hansmann and Mattei's analysis of asset partitioning in trust law, which Lee calls the 'external aspect' of the trust, ${ }^{92}$ Lee focuses on the inability of the trustee's personal creditors to reach the trust property.

Lee's focus on asset partitioning for the trustee is incomplete. In the Chinese trust, the settlor, not the trustee, is the technical owner of the trust property. Recall that at the outset of Lee's essay, she tells us that in the Chinese trust there is no required conveyance of the trust property to the trustee. Instead the settlor remains the owner, subject to a duty to keep the trust property separate from the settlor's other property. The asset partitioning literature that Lee follows emphasizes the separateness from the trustee's personal obligations because in the Anglo-American

88 See Delaware Statutory Trust Entity Act $\$ 3804$ (2011); Uniform Statutory Trust Entity Act $\$ \$ 307-8$ (2009); see also R. H. Sitkoff, "Trust as "Uncorporation": A Research Agenda' [2005] University of Illinois Law Review 31.

${ }^{89}$ In this taxonomy, which I intend to develop in future work, I am putting to the side the constructive trust, which is a remedy, and the resulting trust, which is an equitable reversionary interest.

90 See Restatement (Third) of Trusts, above, note 5, $\$ 25$, cmt. e; UTC $\$ 505$.

${ }^{91}$ Lee, 'Convergence and Divergence', Chapter 17 in this volume, p. 424.

92 Ibid., pp. 424, 427. 
tradition the trustee is the legal owner of the trust property. This is the feature of trust law - in effect, the splitting the trustee into two separate persons - that cannot be replicated by mere contract. But if the settlor and not the trustee owns the trust property, then the locus of the partitioning or separateness issue shifts to the settlor, and the question is whether the settlor becomes in effect two separate persons.

Lee's discussion of the Chinese assimilation of the trust concept is provocative and interesting. Although China follows the civilian tradition of indivisible ownership, the Chinese were able to replicate the fiduciary governance of Anglo-American trust law by direct imposition of rights, powers and duties that parallel those of Anglo-American trust law. In this sense, the Chinese experience lends support to the contractarian model of trust law. But we also find in the Chinese trust the existence of the asset partitioning rules that separate organizational law, of which trust law is a species, from mere contract law. Although Lee emphasizes the Chinese replication of Anglo-American trust governance, her essay suggests an equally interesting replication of asset partitioning, though this point is not as well developed and is lacking with respect to the settlor's continued ownership of the trust property and the rights of the settlor's personal creditors.

\section{Conclusion}

Organizational law supplies a set of contractarian rules, some of a fiduciary character, that provide for the governance of the organization. These are the rules that provide for the powers and duties of the managers and the rights of the beneficial owners. Organizational law also supplies a set of proprietary rules that provide for asset partitioning. These are the rules that provide for the separation of the property of the organization from the property of the organization's managers, beneficial owners and other insiders. Because trust law follows this pattern, supplying both fiduciary governance and asset partitioning, the law of trusts is a species of organizational law. ${ }^{93}$

The chapters for this volume by Thomas P. Gallanis and by Rebecca Lee both emphasize the importance of the fiduciary governance rules of trust law. Gallanis argues that trust fiduciary law makes an important contribution. I have suggested that this contribution can be understood

93 See Sitkoff, 'Agency Costs Theory', above, note 2, 627-34. 
primarily as minimizing transaction costs through provision of a standard-form contract suited to the agency problem underlying the trust structure. Fiduciary law also supplies mandatory rules that serve protective and categorization functions, and penalty default rules that are meant to alter the parties' negotiation dynamic. Lee argues that the Chinese experience with assimilating the trust, in which the Chinese have replicated Anglo-American trust fiduciary law without separate concepts of law and equity, shows that the governance rules but not legal and equitable ownership are part of the irreducible core of trusteeship. I have suggested several follow-up questions for Lee, in particular about the nature of asset partitioning in the Chinese trust given the settlor's continued ownership of the trust property.

More than fifteen years ago, John Langbein suggested that ' $\mathrm{t}$ ]rust is a hybrid of contract and property, and acknowledging contractarian elements does not require disregarding property components whose convenience abides'. ${ }^{94}$ The claim that runs through this chapter, a commentary on those by Gallanis and Lee, is that such hybrids are properly regarded as organizations. Trust law is organizational law.

94 Langbein, 'Contractarian Basis', above, note 4, 669. 